\title{
Custom inspection on drunk driving in traffic accident injury
}

\author{
MENG Fanshan*, WANG Shuhou, ZHAO Yulan \\ From 2012 PLA Emergency Medicine Annual Congress \\ Beijing, China. 9-12 November 2012
}

\section{Objective}

To investigate the effect of custom inspection on drunk driving in traffic accident injury.

\section{Methods}

In order to find out the effect of the strict check on drunk driving in traffic accident injury, we investigated the patients with traffic accident injury, who were sent to our hospital during the period from August to December, 2009, and compared them with those in the same period of 2007 and 2008.

\section{Results}

The numbers of patients with traffic accident injury and the times of ambulance turnout in 2009 were fewer than those in 2007 and 2008. The percentage of critical patients and the number of car related traffic injury were decreased too.

\section{Conclusion}

Custom inspection on drunk driving can effectively decrease the number of traffic accident injury and lower the percentage of critical patients.

Submit your next manuscript to BioMed Central and take full advantage of:

- Convenient online submission

- Thorough peer review

- No space constraints or color figure charges

- Immediate publication on acceptance

- Inclusion in PubMed, CAS, Scopus and Google Scholar

- Research which is freely available for redistribution

\section{() Biomed Central}

\section{Biomed Central}

